\title{
Holocene Boulder Beach Eroded from Chromite and Dunite Sea Cliffs at Støypet on Leka Island (Northern Norway)
}

\author{
Markes E. Johnson (D) \\ Department of Geosciences, Williams College, Williamstown, MA 01267, USA; mjohnson@williams.edu; \\ Tel.: +1-413-2329
}

Received: 29 June 2020; Accepted: 19 August 2020; Published: 21 August 2020

\begin{abstract}
This project examines the role of high-latitude storms degrading a Holocene coast formed by igneous rocks composed of low-grade chromite ore and dunite that originated within the Earth's crust near the upper mantle. Such rocks are dense and rarely exposed at the surface by tectonic events in the reconfiguration of old ocean basins. An unconsolidated boulder beach occupies Støypet valley on Leka Island in northern Norway, formerly an open channel 10,000 years ago when glacial ice was in retreat and rebound of the land surface was about to commence. Sea cliffs exposing a stratiform ore body dissected by fractures was subject to wave erosion that shed large cobbles and small boulders into the channel. Competing mathematical equations are applied to estimate the height of storm waves impacting the channel floor and cliffs, and the results are compared with observations on wave heights generated by recent storms striking the Norwegian coast with the intensity of an orkan (Norwegian for hurricane). Lateral size variations in beach clasts suggest that Holocene storms struck Leka Island from the southwest with wave heights between 5 and $7.5 \mathrm{~m}$ based on the largest beach boulders. This result compares favorably with recent high-latitude storm tracks in the Norwegian Sea and their recorded wave heights. The density of low-grade chromite ore $\left(3.32 \mathrm{~g} / \mathrm{cm}^{3}\right)$ sampled from the beach deposit exceeds that of rocks like limestone or other igneous rocks such as rhyolite, andesite, and basalt taken into consideration regarding coastal boulder deposits associated with classic hurricanes in more tropical settings.
\end{abstract}

Keywords: coastal storm deposits; storm surge; hydrodynamic equations; high-latitude settings

\section{Introduction}

Global Geoparks authorized by the United Nations Educational, Scientific and Cultural Organization (UNESCO) have expanded in number since inception in 2000 to more than 160 units in 45 different countries. Geology in one form or another is the educational focus of such parks, but with an emphasis on geotourism in support of conservation and the socioeconomic development of rural areas [1]. Remote by nature, many islands possess features of extraordinary significance worthy of development as geoparks. As an example, Iceland is iconic for its status as an island that straddles an expanding oceanic ridge. The island boasts of two UNESCO geoparks, but the potential for several additional parks is anticipated by local planners [2]. In Norway, the Trollfjell (Troll Mountain) Geopark is an example of a well-organized geopark in a remote part of that country near the Arctic Circle that includes many coastal islands with small communities. Stunning coastal scenery that enfolds world-class aspects of geology in the Trollfjell Geopark also includes elements of regional folklore that relate the landscape to its human occupation. Established in 2010, the National Norwegian Geological Monument on Leka Island within the greater geopark boosts the program beyond that envisioned by UNESCO [3]. The monument not only abets an increase in commerce through geotourism but also 
attracts working geologists and geomorphologists who otherwise may not have known about the place. The dynamics foster a feed-back loop, through which a steady increase in knowledge adds to the overall significance of geoheritage. The present contribution on a unique boulder beach and the interpretation of its hydrodynamics is offered in that spirit.

The aim of this paper is to review unusual physical traits along one of the monument's well-marked trails at Støypet near the north shore of Leka Island. In Norwegian, the word støypet may be translated as "the foundry" in reference to the rare igneous rocks and chromite ore concentrated at that place $[4,5]$, although there is no evidence that mineral extraction and smelting took place any time since human occupation began in the earliest Holocene. The unique aspect of Støypet as a geomorphologic and cultural site is the accumulations of a boulder beach dominated by "rolling stones" eroded from adjacent rocky shores composed of dunite and chromite. These ultramafic rocks originated in the deepest part of the earth's crust near the discontinuity with the upper mantle and register high values of specific gravity that give them greater mass. The implication is that wave heights affecting coastal surge were sufficiently powerful to remove joint-bound blocks from sea cliffs that resulted in unusually dense boulders. The same mathematical equations for estimation of wave heights as applied previously to other shores with boulders derived from more common source rocks of lesser mass, including limestone, rhyolite, andesite, and basalt [6-9], are newly applied at Støypet. In addition, the present-day steering winds and wave dynamics characteristic of Norway's Arctic Circle region [10] are reviewed in the context of prominent storms during recent decades in order to appraise the likely direction of wave impact responsible for the boulder beach at Støypet.

\section{Geographical and Geological Setting}

Open to the Norwegian Sea off the coast of northern Norway, Leka Island lies south of the Arctic Circle within the Trollfjell Geopark (Figure 1a). Together with smaller Madsøya, the two islands combine for a total area of $57 \mathrm{~km}^{2}$ (Figure 1b), and support a population of about 500 inhabitants. From the mainland, the island is accessible by ferryboat across a 4-km wide strait. Norway's National Geological Monument offers an extensive system of hiking trails that are well laid out and include educational trail-side markers with texts in Norwegian, English, and German. Several themes combine to make the park an attractive experience, including local folklore. The island's most prominent landmark is a monolith at the side of Lekamøyhammaren Mountain (Figure 1b), said to embody a troll maiden. The monolith (Figure 2a) is a sea stack composed of the igneous rock gabbro, now isolated inland by postglacial rebound at an elevation $100 \mathrm{~m}$ above present-day sea level. Other effects of coastal erosion are evident around the sea stack, where former sea cliffs show deep wear in the form of surge channels cut and polished in gabbro basement rocks (Figure 2b). Detailed work by Høgaas and Sveia (2015) that covers the inner (southeastern) part of Leka Island outlines slightly earlier shore erosion by ice scour during the Younger Dryas interval of 12.8 to 11.5 thousand years ago [11].

Geologically, Leka Island is renowned for exposures of the igneous rocks dunite and harzburgite. These are attributed to formation around the boundary between the Earth's lower crust and upper mantle, known as the Mohorovicic Discontinuity [4]. Such rocks are accessible in few other places around the world where their occurrence is justly celebrated, most notably in Canada's Gros Morne National Park in western Newfoundland [12]. Enrichment in minerals belonging to the platinum group, including gold, platinum, and chromium, also occurs as a dense chromite ore associated with dunite on Leka Island [5]. Brought to the surface by tectonic events, these parent rocks were locally subject to Holocene coastal erosion. Thus, today's Leka Island represents a rare convergence of factors related to the geology of deep ocean crust and the geomorphology of recent marine coastal erosion.

On the island's north shore (Figure 1c), access to a Holocene valley crosses a seam of banded chromite framed by outcrops of dunite (Figure 3) that is described by geopark signage. It is noticeable that the chromite bands at this locality are dissected by joints and fractures typical of exfoliation under subaerial conditions comparable to those in former sea cliffs elsewhere in Støypet valley. 


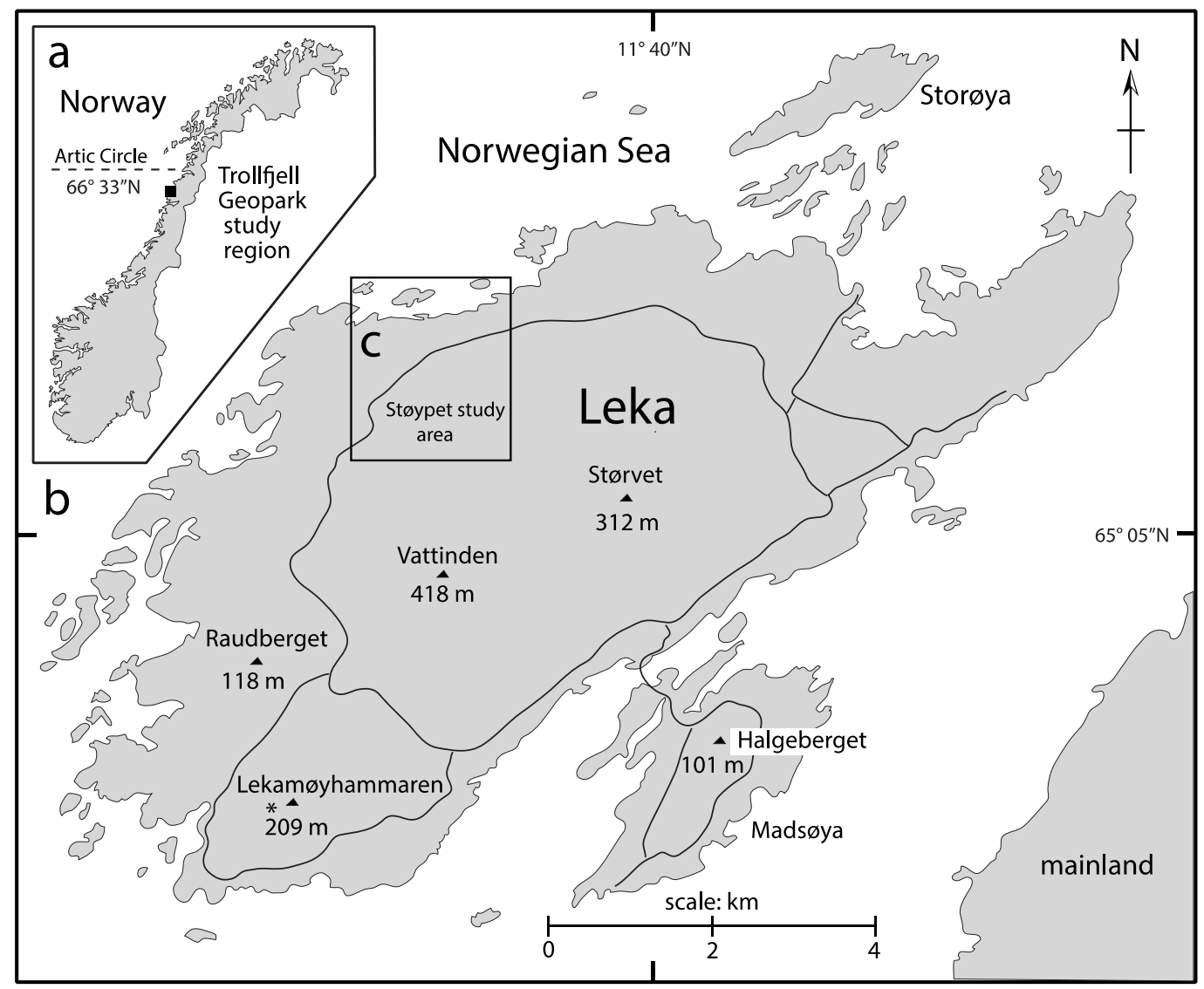

Figure 1. The west coast of Norway and Leka Island: (a) Norway, showing latitude of the Arctic Circle and region of the Trollfjell Geopark, (b) Leka Island and Madsøya with details on highland peaks and location of the Leka maiden monolith (asterisk), and (c) inset showing location the Støypet study site.
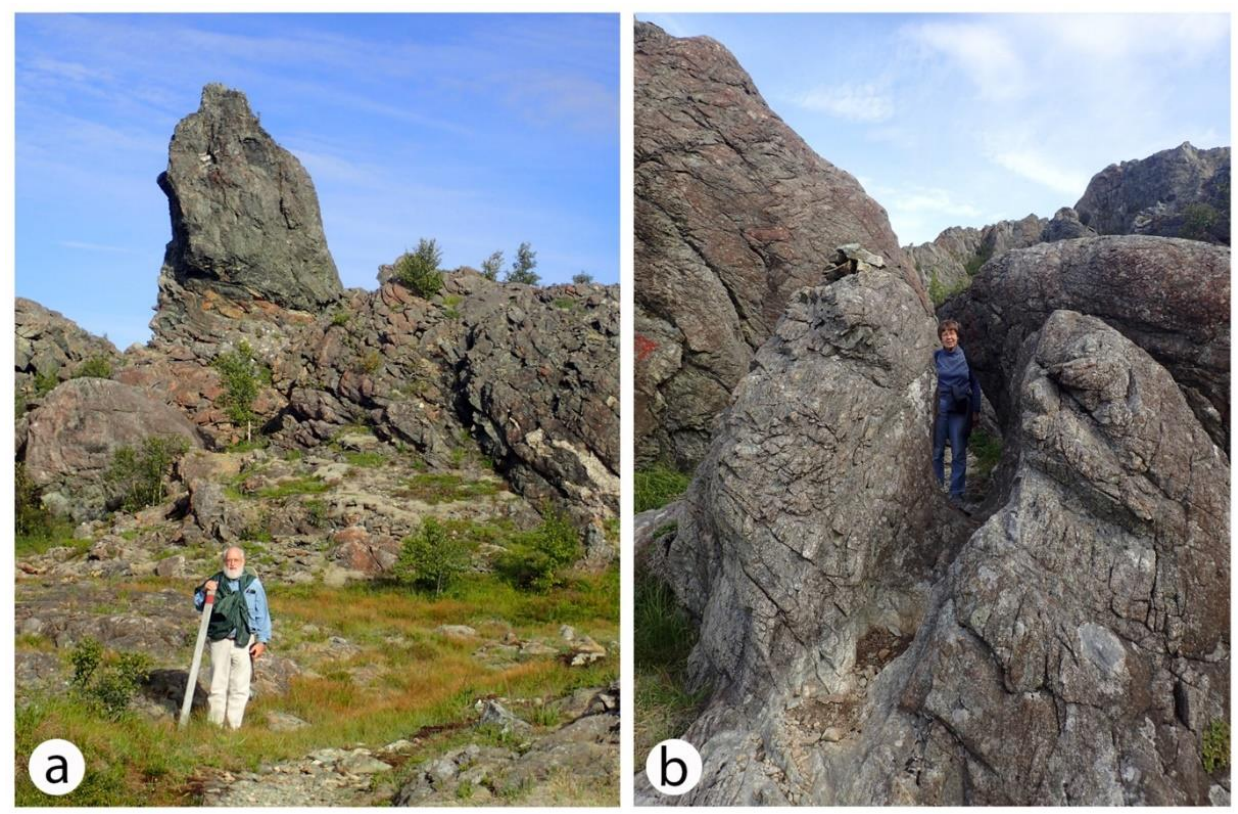

Figure 2. The raised shoreline now about $100 \mathrm{~m}$ above sea level at the base of Lekamøyhammaren Mountain (see Figure 1b): (a) Gabbro sea stack attributed by legend to the stony embodiment of the Leka troll maiden (author for scale) and (b) wave-polished surge channel eroded in gabbro close by the sea stack (figure for scale). 


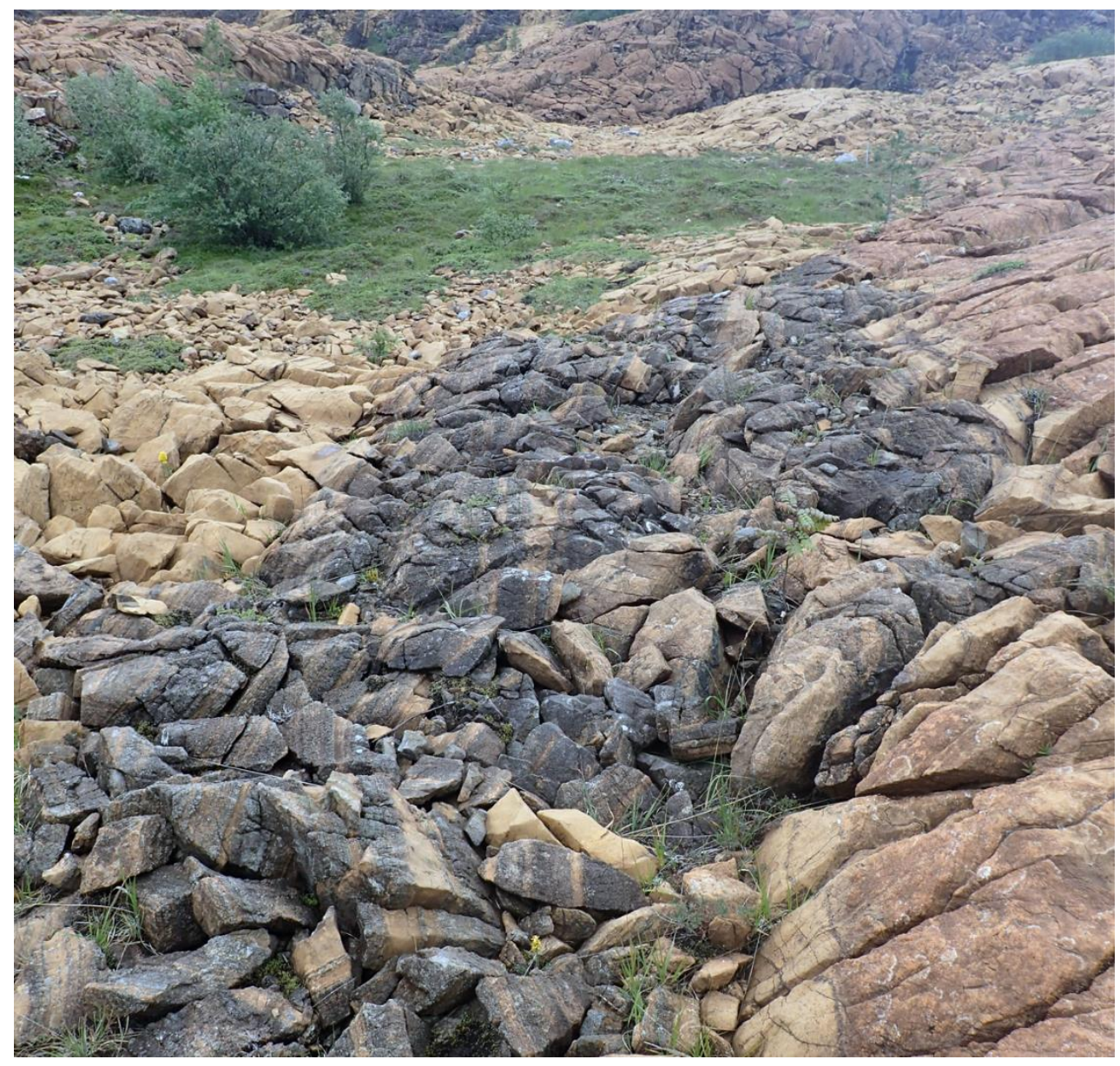

Figure 3. Rough exfoliation of chromite bands (dark rocks) and dunite (pale rocks) at the northeast (NE) end of Støypet valley $250 \mathrm{~m}$ from the island ring road on the access trail.

\section{Materials and Methods}

\subsection{Data Collection}

Leka Island was visited in July 2019, when the original data for this study were collected from an unconsolidated beach deposit dominated by chromite cobbles and boulders at Støypet. Individual clasts from three stations each limited to collection within a 2-m span were measured manually in three dimensions perpendicular to one another (long, intermediate, and short axes). The stations are confined to a southwest (SW) to northeast (NE) trending valley that contains the Støypet beach deposit. Differentiated from cobbles, the base definition for a boulder adapted in this exercise is that of Wentworth (1922) for an erosional clast equal or greater than $256 \mathrm{~mm}$ in diameter [13]. No upper limit for this category is defined in the geological literature [14]. Triangular plots were employed to show variations in clast shape, following the design of Sneed and Folk (1958) for river pebbles [15]. Comparative data on maximum cobble and boulder dimensions were fitted to bar graphs to show size variations in the long and short axes from one sample to the next. Fracture patterns in chromite layers exposed along the valley floor and walls can be examined in two dimensions only, but roughly rectangular outlines can be appraised for a comparison between the original source rocks and range of three-dimensional clast sizes found in the beach deposit. A chromite cobble from the top of Støypet was collected for laboratory determination of density in order to yield weight and volume assigned as a function of equal displacement when submerged in a beaker of water. The commercial "Tour Map" for Leka from 2017 [16] was scanned and adapted in preparation of a detailed base map representing Støypet topography around the study site close to the north shore of Leka Island (see Figure 1c). 


\subsection{Hydraulic Model}

Dependent on the calculation of density for low-grade chromite, a hydraulic model may be applied to predict the force needed to remove cobbles and boulders from a rocky shoreline with joint-bound blocks as a function of wave impact. Chromite is an igneous rock that forms in the deepest part of the Earth's crust with variable thicknesses due to zonal banding. These factors mitigate the size and shape of blocks loosened by storm waves once the crustal rocks are brought to the surface. Herein, two formulas were applied to estimate the size of storm waves against joint-bound blocks derived, respectively, from Equation (36) in the work of Nott [17] and from an alternative approach using the velocity equations of Nandasena et al. (2011) [18] as applied by Pepe et al. (2018) [19]:

$$
\begin{gathered}
H s=\frac{\left(\frac{\rho_{s}-\rho_{w}}{\rho_{w}}\right) a}{C_{l}} \\
H_{S}=\frac{2 \cdot\left(\frac{\rho_{s}-\rho_{w}}{\rho_{w}}\right) \cdot c \cdot\left(\cos \theta+\mu_{s} \times \sin \theta\right)}{C_{l}} / 100
\end{gathered}
$$

where $H s=$ height of the storm wave in meters at breaking point, $\rho_{s}=$ density of the boulder $\left(\right.$ tons $/ \mathrm{m}^{3}$ or $\left.\mathrm{g} / \mathrm{cm}^{3}\right), \rho_{w}=$ density of water at $1.02 \mathrm{~g} / \mathrm{mL}, a=$ length of boulder on the long axis in $\mathrm{cm}, \theta$ is the angle of the bed slope at the pre-transport location ( $1^{\circ}$ for joint-bounded boulders), $\mu_{s}$ is the coefficient of static friction $(=0.7), C_{1}$ is the lift coefficient $(=0.178)$, and $c$ is length of boulder on the short axis in $\mathrm{cm}$. Equation (1) is sensitive only to the length of a boulder on the long axis, whereas Equation (2) is more sensitive to the length of a boulder on the short axis. Therefore, some differences are expected in the estimates of $H_{S}$. It is noted that Equation (2) (above) was shown incorrectly in a previous paper dealing with basalt boulder beds from Santa Maria Island in the Azores [9], although the accompanying calculations were performed according to the proper formula.

\section{Results}

\subsection{Base Map}

The base map for the study site at Støypet defines a narrow valley that crosses a topographic saddle between prominent highlands at Steinstind and Hagafjellet, respectively, 190 and $345 \mathrm{~m}$ above present-day sea level (Figure 4). The valley is accessed from two endpoints on the Leka Island ring road and follows a well-marked geopark trail for a distance of $2 \mathrm{~km}$. At the topographic saddle between Steinstind and Hagafjellet, the NE to SW trending valley is $50 \mathrm{~m}$ wide at an elevation just under $100 \mathrm{~m}$ above present sea level (Figure 5a).

The park trail leading from the NE trailhead (Figure 4) climbs a smooth gradient through the deposit to the top located in mid-valley (Figure 5). The view to the northeast across the slope includes the enclosing valley walls with interbedded chromite-dunite layers (Figure 6). Based on horizontal distance in proportion to vertical rise, the slope from the NE direction amounts to $5^{\circ}$. The slope on the opposite side that descends to the SW is similar in vertical drop over horizontal distance, but is broken by a series of cobble-boulder ridges that make it difficult to project a simple gradient. 


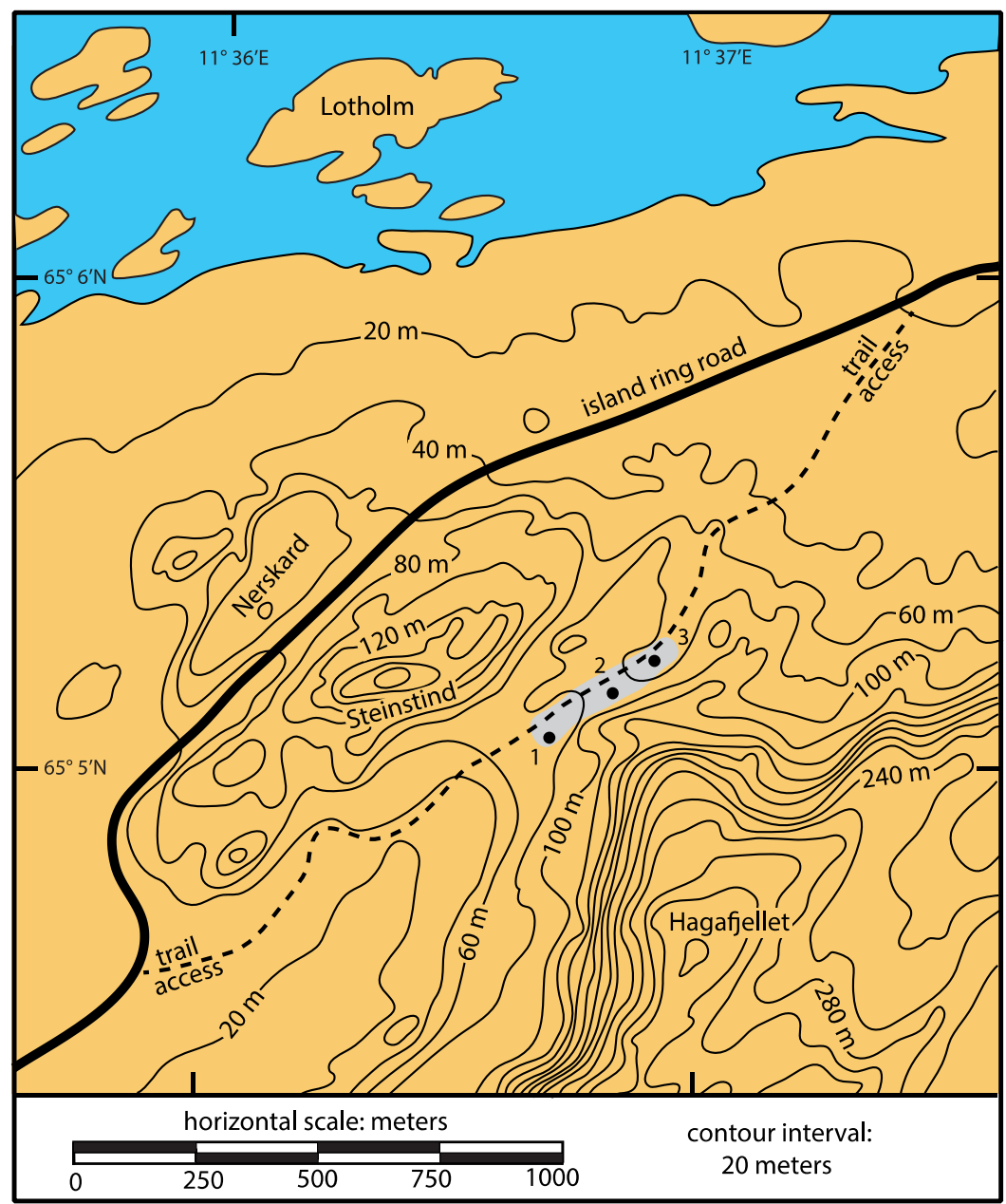

Figure 4. Topographic base map for the study area and access trail at Støypet in the National Norwegian Geological Monument on Leka Island. The shaded area near the center represents the limits of an unconsolidated cobble/boulder deposit at the pass between Steinstind and Hagafjellet. Black dots mark the location of three sample sites. See Figure 1c for orientation with respect to the rest of the island. See Figure 1c for location on Leka Island.
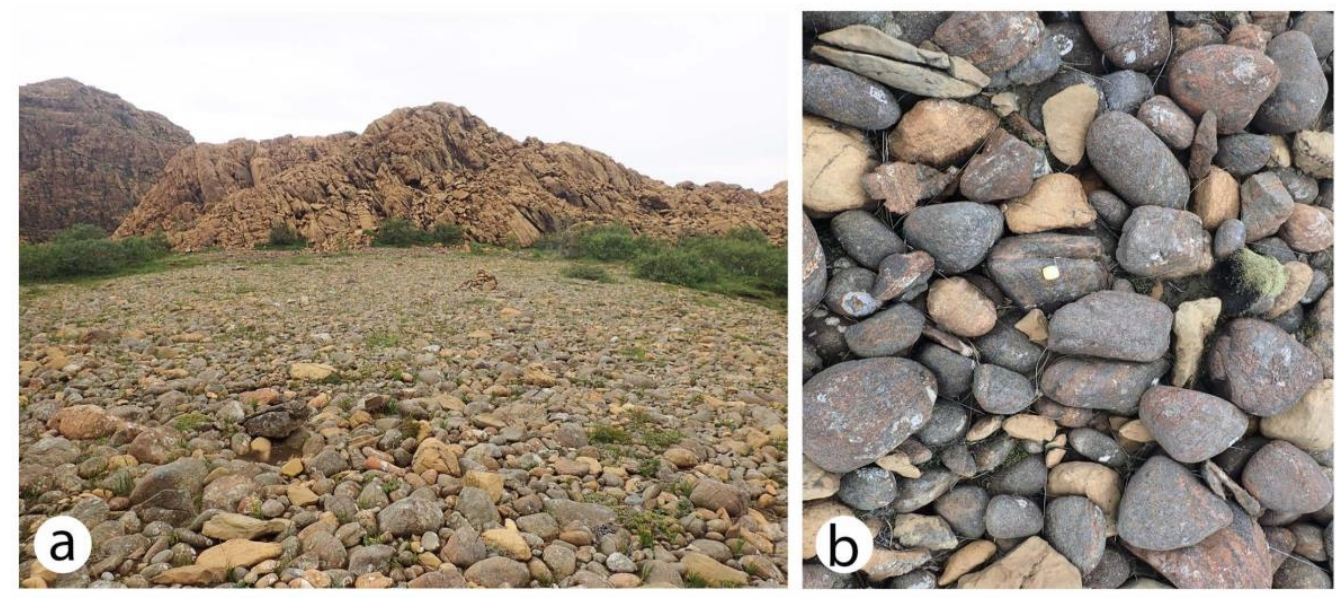

Figure 5. Details at the top of Støypet within a southwest to northeast (SW-NE) trending valley: (a) view to the northwest across the cobble-boulder field perpendicular to the trend of the valley and (b) close-up of cobbles and boulders dominated by chromite (darker rocks) with the clast at the center (marked by tape-measure case) having a diameter of $26 \mathrm{~cm}$ across the long axis. 


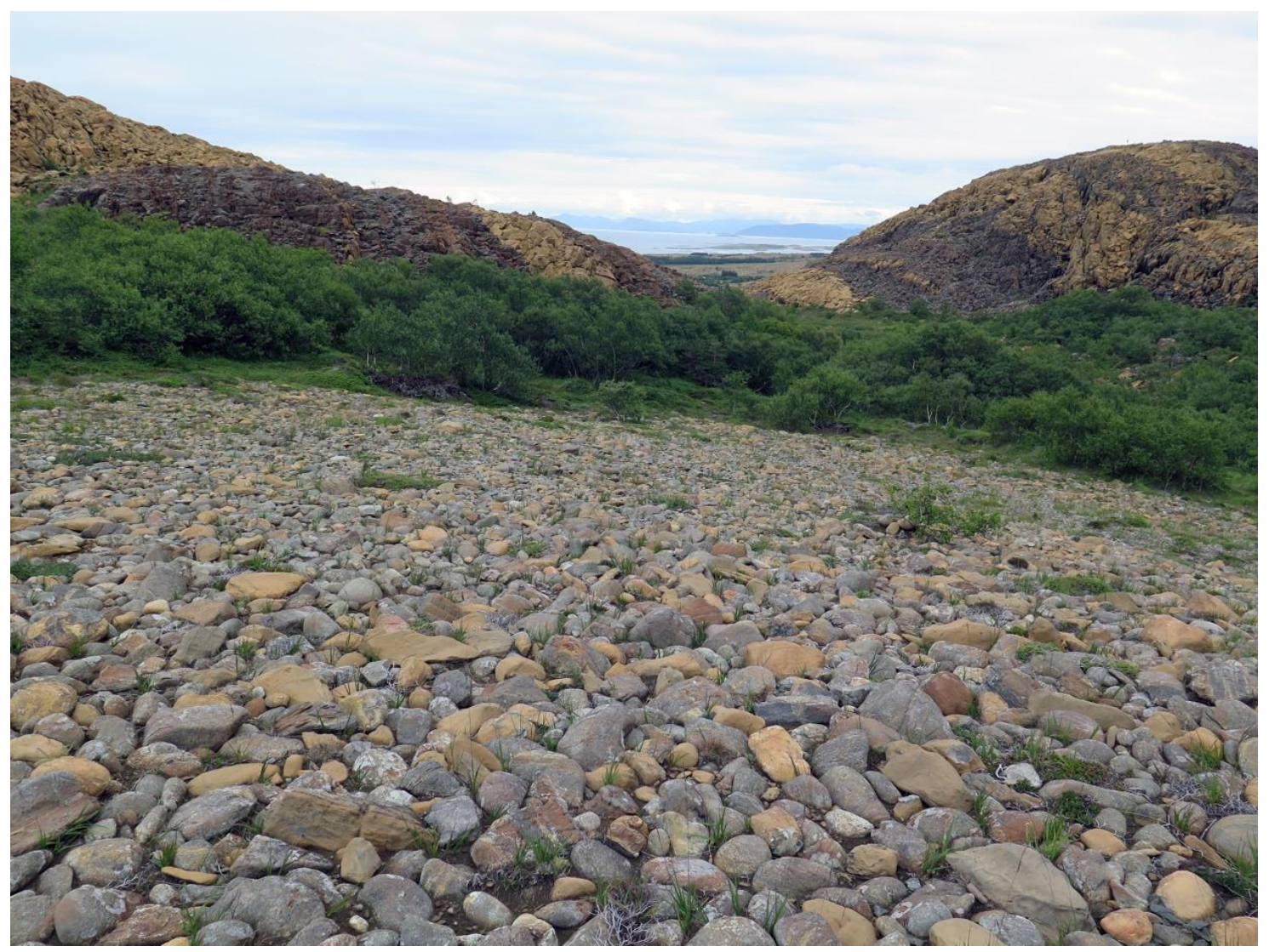

Figure 6. View from the mid-valley beach deposit over the slope descending to the NE.

\subsection{Fracture Pattern in Støypet Valley Chromite Layers}

The fracture pattern in chromite layers interbedded with dunite is characteristic of basement rocks exposed in the valley floor (Figure 3) and south wall of Støypet valley near its opening to the northeast (Figure 7a). In closer view (Figure $7 \mathrm{~b}$ ), the pattern of vertical joints seen in two dimensions defines columns roughly $40 \mathrm{~cm}$ wide. The resulting fractures in combination with horizontal layering results in a two-dimensional outline of rectangular shapes. A set of measurements in two dimensions is represented by a small sample from the outcrop surface. The larger rectangle defined by fractures at the center of Figure $7 \mathrm{~b}$ is $33 \times 21 \mathrm{~cm}$. Smaller rectangles in the layer directly above measure $16 \times 9 \mathrm{~cm}$ and $11.5 \times 10 \mathrm{~cm}$, respectively. Not shown in its entirety (Figure $7 \mathrm{~b}$ ), a much larger rectangle at the side has a height of at least $43 \mathrm{~cm}$. This general pattern would have been subject to hydraulic pressure and plucking during wave impact in the early Holocene when Støypet valley was first flooded. Initially, any blocks so removed from chromite sea cliffs would have been rectilinear in three dimensions prior to the rounding of cobbles and small boulders that resulted from clast abrasion. The size range of cobbles and small boulders in the boulder beach at the top of Støypet (Figure 5a) readily fit with this pattern of fracture-size and shapes. Calculations for $80 \%$ of volume from a three-dimensional cubic solution (Appendix A and Tables A1-A3) is a rough estimate for the size reduction of individual cobbles and boulders that underwent abrasion after removal from sea cliffs during contact with one another under storm conditions. 

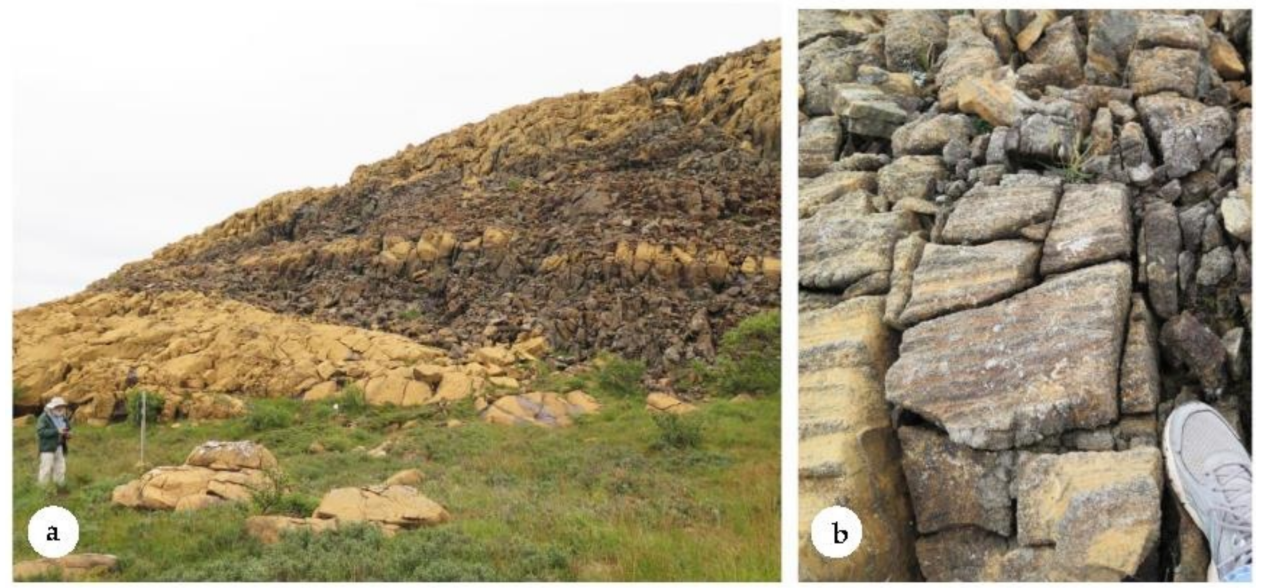

Figure 7. Natural fracture pattern in chromite layers interbedded with dunite exposed in the south wall of Støypet valley: (a) view to the south at the northeast end of Støypet valley showing chromite layers approximately $4 \mathrm{~m}$ thick and (b) close-up view showing vertical joints spaced about $40 \mathrm{~cm}$ apart.

\subsection{Chromite Ore Density}

The sample of low-grade chromite ore collected at Støypet yielded a value of $3.32 \mathrm{~g} / \mathrm{cm}^{3}$ for density based on a small cobble weighing $83 \mathrm{gm}$ and displacing an equivalent volume of water amounting to $25 \mathrm{~m}$. The number is derived by dividing weight by volume. This value was applied uniformly to all clasts listed in Tables A1-A3.

\subsection{Comparative Variation in Clast Shapes}

Raw data on clast size in three dimensions collected from each of the three sample sites are shown in Appendix A (Tables A1-A3). With regard to shape, points representing individual cobbles and boulders are fitted to a set of Sneed-Folk triangular diagrams (Figure 8a-c). The spread of points across these plots consistently shows a strong similarity in the variation of shapes from one sample to another. Few points fall into the upper-most triangle, which represents an origin from a perfectly cube-shaped endpoint as a joint-bound block. The majority of points in each sample fall within the middle part of the two tiers below the top triangle. Those points clustered at the core of any given triangular plot are representative of clasts for which two of the three dimensions are close in value. Relatively few points fall into the middle-right and lower-right domains of the field, which signify a tendency toward development of elongated shapes eroded from source rock exposed in sea cliffs. The composite slope of points suggests a diagonal trend in orientation, although the majority of points cluster vertically within the two central boxes. There is a total absence of points plotting within the left side and lower left part of the plots. The overall aspect of distributed points in these plots signifies the rounding of clasts in which two of the dimensions (preferentially the maximum and intermediate lengths) are closely matched. 


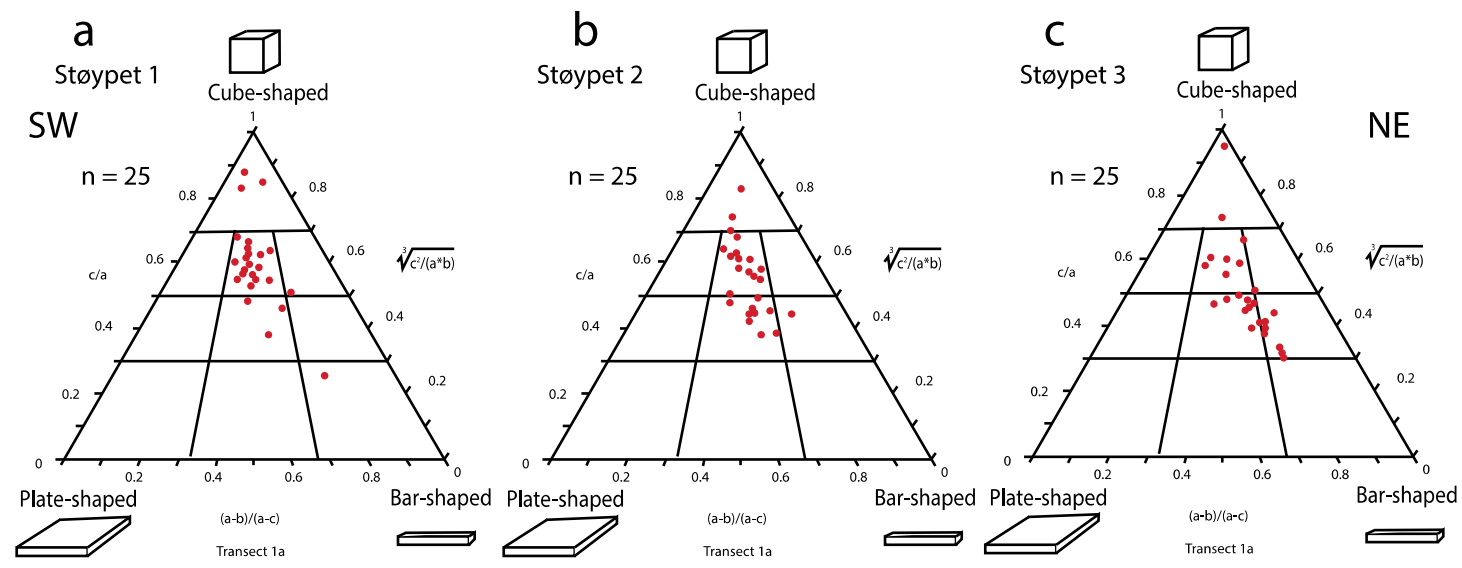

Figure 8. Set of triangular Sneed-Folk diagrams used to appraise variations in cobble and boulder shapes: (a) trend from sample 1 on the SW flank of Støypet, (b) trend sample 2 at the top, and (c) Trend from sample 3 on the NE flank of Støypet.

\subsection{Comparative Variation in Clast Sizes}

Clast size is conveniently plotted on bar graphs as a function of maximum and minimum length drawn from the original data (Tables A1-A3). The results for each of three field samples are paired according to size intervals at $5-\mathrm{cm}$ intervals with the boundary between large cobbles and small boulders clearly marked at a diameter above $25 \mathrm{~cm}$ (Figure 7). The field locality for sample 1 sits below the crest of the pass between Steinstind and Hagafjellet on the SW side of Støypet valley about $75 \mathrm{~m}$ above sea level (Figure 4). The ratio of cobbles to boulders from the sample drawing on maximum clast length is 2:3 (Figure 9a). An equal number of large cobbles and small boulders plot adjacent to one another in bins at the definitional boundary, but the plot is skewed with two individual boulders having a maximum length between 41 and $50 \mathrm{~cm}$. The general shape of clasts from this sample is demonstrated by comparison with the plot for minimum length in which the majority of clasts align below the boundary between cobbles and boulders (Figure 9b). The field locality for sample 2 occurs at the top of the pass between Steinstind and Hagafjellet at the midpoint of Støypet valley just below $100 \mathrm{~m}$ in altitude (Figures 4 and 5). Drawing on data for maximum clast length (Table A2), the ratio of large cobbles to small boulders is 1:7 (Figure 9c), which is significantly different from the example in sample 1 (Figure 9a). The number of clasts that plot adjacent to one another in bins at the definitional boundary are sharply divergent, with small boulders outnumbering large cobbles by more than 3 to 1 . The graphs for maximum clast length in Figure 9a, $c$ are more alike with respect to outliers of boulders having a maximum length between 41 and $50 \mathrm{~cm}$. With regard to the range in clast sizes drawn from the short axis, sample 2 includes no boulders at all (Figure 9d), which is a departure from sample 1 in this regard (Figure 9b). 


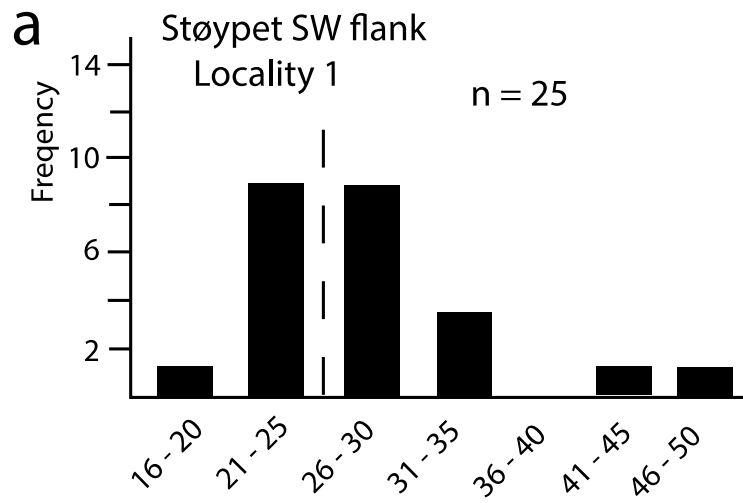

Clast size (long axis) in centimeters

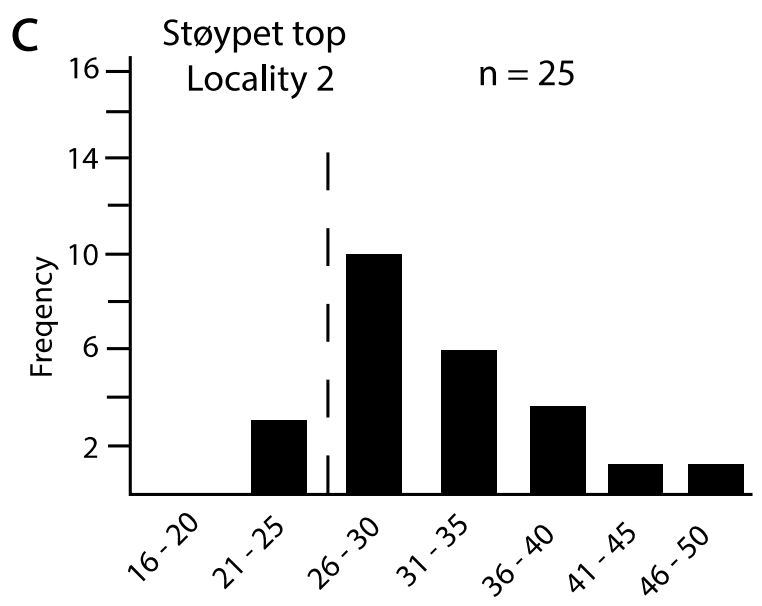

Clast size (long axis) in centimeters

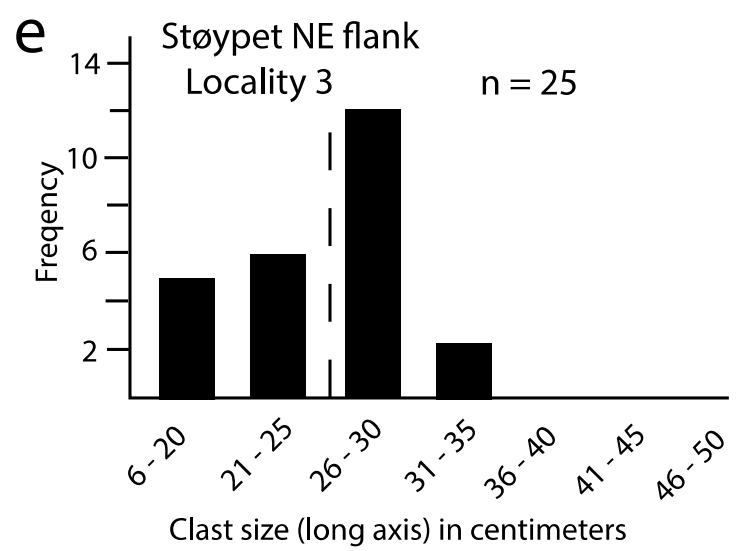

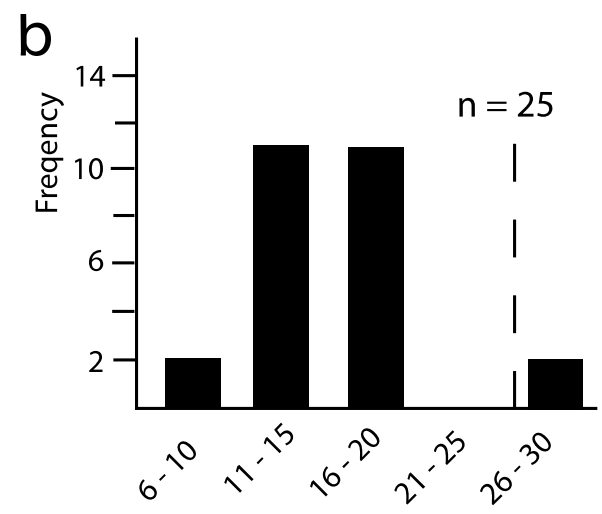

Clast size (short axis) in centimeters

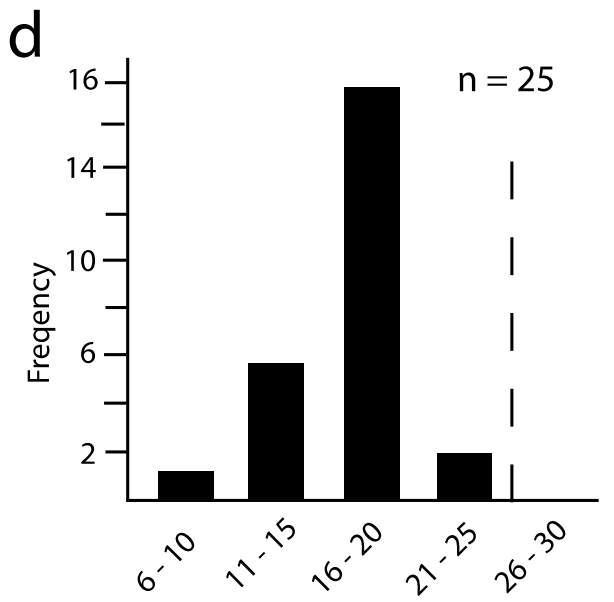

Clast size (short axis) in centimeters

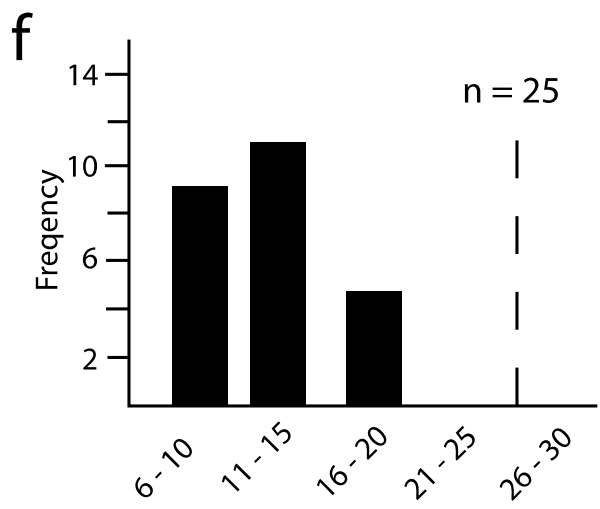

Clast size (short axis) in centimeters

Figure 9. Set of bar graphs used to contrast variations in maximum and minimum clast length from three samples in Støypet valley: $(\mathbf{a}, \mathbf{b})$ bar graphs from Locality 1 on the SW flank of the deposit, $(\mathbf{c}, \mathbf{d})$ bar graphs from Locality 2 at the top of Støypet, and $(\mathbf{e}, \mathbf{f})$ bar graphs from Locality 3 on the NE flank of the deposit. Dashed line (offset to represent $26.6 \mathrm{~mm}$ ) marks the boundary between large cobbles and small boulders.

Like the field locality for sample 1, sample 3 sits at an elevation about $75 \mathrm{~m}$ above sea level but on the opposite NE side of Støypet valley below the crest of the pass (Figure 4). Based on data for maximum clast length in this sample (Table A3), the ratio of cobbles to boulders is more balanced, but the quantity of boulders outnumbers that for cobbles and the ratio between large cobbles and boulders in adjacent bins is 1:2 (Figure 9e). There exist fewer outliers of larger boulders in this sample 
compared to samples 1 and 2 and the number of smaller cobbles in the opposite extreme also exceeds that found in samples 1 and 2 (compared Figure 9a,c,e). Data plotted in bar graphs on the basis of the shortest axis on clasts from sample 3 not only lack boulders but also the class of largest cobbles in size between 21 and $25 \mathrm{~cm}$. In total (Figure 9), the side-by-side plots for sample 3 exhibit a marked downward shift in clast size compared to those from samples 1 and 2.

\subsection{Storm Intensity as Function of Estimated Wave Height}

Average clast sizes and maximum boulder sizes from the three field samples are summarized in Table 1, allowing for direct comparison of mean values for all clasts, as well as values for the largest clasts in each sample based on Equations (1) and (2) derived from the work of Nott [17] and Pepe et al. [19]. The Nott formula [17] shown in Equation (1) yields an average wave height of 3.6 $\mathrm{m}$ for the extraction of joint-bound blocks from chromite sea cliffs and their subsequent transfer as beach cobbles and boulders in samples 1-3. According to these results, the mean wave height that impacted shores along the midpoint of Støypet valley and led to the boulder beach on the saddle between Steinstind and Hagafjellet was greatest at $4.1 \mathrm{~m}$. The formula influenced by Pepe et al. [19] showed in Equation (2) yields higher values across all categories with the mean wave height also at the valley's midpoint reaching a value of $4.8 \mathrm{~m}$. Taking into consideration the largest individual boulders from the three samples (Tables A1-A3), Equation (2) differs from Equation (1) in showing a decline in wave heights from the SW end to the NE end of the valley with the most dramatic reduction to $5.2 \mathrm{~m}$ (Table 1).

Table 1. Summary data from Appendix A (Tables A1-A3) showing maximum bolder size and estimated weight compared to the average values for sampled boulders from each of the transects together with calculated values for wave heights estimated as necessary for boulder-beach mobility. Abbreviations: Max. = maximum, $\mathrm{EAWH}=$ estimated average wave height, $\mathrm{EMWH}=$ estimated maximum wave height.

\begin{tabular}{|c|c|c|c|c|c|c|c|c|c|}
\hline $\begin{array}{l}\text { Støypet } \\
\text { Locality }\end{array}$ & $\begin{array}{l}\text { Number } \\
\text { of } \\
\text { Samples }\end{array}$ & $\begin{array}{c}\text { Average } \\
\text { Boulder } \\
\text { Volume } \\
\left(\mathrm{cm}^{3}\right)\end{array}$ & $\begin{array}{c}\text { Average } \\
\text { Boulder } \\
\text { Weight } \\
\text { (kg) }\end{array}$ & $\begin{array}{c}\text { EAWH } \\
\text { (m) } \\
\text { Nott } \\
{[17]}\end{array}$ & $\begin{array}{c}\text { EAWH } \\
\text { (m) } \\
\text { Pepe et } \\
\text { al. [19] }\end{array}$ & $\begin{array}{l}\text { Max. } \\
\text { Boulder } \\
\text { Volume } \\
\left(\mathrm{cm}^{3}\right)\end{array}$ & $\begin{array}{l}\text { Max. } \\
\text { Boulder } \\
\text { Weight } \\
\text { (kg) }\end{array}$ & $\begin{array}{c}\text { EMWH } \\
\text { (m) } \\
\text { Nott } \\
{[17]}\end{array}$ & $\begin{array}{l}\text { EMWH } \\
\text { (m) } \\
\text { Pepe et } \\
\text { al. [19] }\end{array}$ \\
\hline 1 & 25 & 8136 & 27 & 3.6 & 4.6 & 33,600 & 112 & 6.5 & 7.7 \\
\hline 2 & 25 & 9786 & 33 & 4.1 & 4.8 & 21,120 & 70 & 5.2 & 7.2 \\
\hline 3 & 25 & 4949 & 16 & 3.2 & 3.5 & 10,886 & 36 & 3.6 & 5.2 \\
\hline Average & 25 & 7624 & 25 & 3.6 & 4.3 & 21,869 & 73 & 5.1 & 6.7 \\
\hline
\end{tabular}

\section{Discussion}

\subsection{Physiographic Changes in Island Size}

In the context of Leka Island's general physiography, the midpoint of Støypet valley reflects postglacial uplift of the surface from earliest Holocene sea level to nearly $100 \mathrm{~m}$ above contemporary sea level mid-valley. This amount of rebound is commensurate with uplift of the sea stack at the SE end of the island said by legend to embody the Leka troll maiden (Figures 1 and 2a). In terms of physical geography prior to uplift, Støypet valley evolved from an open channel that isolated the adjacent heights of Steinstind and Nerskard as a separate entity from the rest of Leka Island. The core of the smaller island would have stood about $80 \mathrm{~m}$ above earliest Holocene sea level. The high point of Hagafjellet on the opposite side of the channel was $220 \mathrm{~m}$ above earliest Holocene sea level. Cobbles and boulders of chromite and dunite eroded from the facing sea cliffs along the channel began to accumulate as a beach deposit mid-channel, eventually forming a dry connection between the main island and Steinstind. Three archaeological sites are marked on the northwest (NW) embankment overlooking the Støypet channel [16] that were occupied by immigrants who arrived sometime after the local retreat of ice at the end of the Younger Dryas about 11,500 years ago. Cave paintings at nearby Solsem on Leka 
Island are dated to the earliest Bronze Age, although Stone Age finds have been excavated from the cave floor [20]. Precise dating for the onset of human occupation in North Trondelag (including Leka Island) is poorly documented, but data from carbon-14 testing in neighboring Nordland and farther north in Troms and Finnmark indicate a pattern of first settlements spanning 9000 to 6000 years ago [21]. Erosion by ice scour along the inner passage between Leka Island and the Norwegian mainland left a distinctive trace correlated with the Main Line now found at a higher elevation between 106 and $112 \mathrm{~m}$ above today's sea level [11]. Amalgamation of beach deposits during Holocene time added to the base of the mid-channel connection between Steinstind and Hagafjellet as the land on both sides continued to rebound after ice retreat. The loose "rolling stones" deposited in Støypet valley formed a 50-m wide and $300 \mathrm{~m}$ in length plug (Figure 4). In some respects, the deposit on the SW flank may be compared to beach ridges commonly formed in more tropical latitudes as a result of cyclonic storms [22], some of which can be dated by radiometric analysis drawn from coral heads incorporated within distinct ridges. No such method of absolute dating for the testing of storm frequency is possible in Støypet valley, but the centrality of the deposit far from present-day shores at opposite ends of the valley makes it clear that channel erosion ceased long ago.

\subsection{Direction of Holocene Storms}

Application of Equation (1) from Nott [17] and Equation (2) influenced by Pepe et al. [19] differs in results estimating the magnitude of waves impacting sea cliffs along the Holocene Støypet channel, but agrees in the relative ranking of wave energy responsible for transferal of chromite clasts to the three sample sites. Maximum wave energy appears to have focused on the SW part of the channel relative to field sample 1 , followed by a reduction in wave energy mid-channel relative to field sample 2 , with registration of the lowest wave energy in regard to field sample 3 in the NE part of the channel. From these data (Table 1), it may be argued that initiation of the beach deposit occurred in the vicinity of field sample 1, but that beach ridges pushed farther into the channel as typified by field sample 2 . The same amount of surface rebound should have resulted along the entire length of Støypet valley, but the nearly $25 \mathrm{~m}$ difference in elevation comparing the altitude of the deposit's axial midpoint (field sample 2) to the its SW and NE extensions is likely due to the formation of a central storm ridge at the same time when uplift began to occur throughout the rest of the island consistent with that around the Leka maiden's Holocene sea stack (Figure 1). The wider mouth of Støypet channel and its emergent valley at one end (Figure 4) also may have influenced the funneling of storm waves that entered from the SW. The smaller clast sizes evident from field sample 3 (Table A3 and Figure 9e,f) can be interpreted as a result of waves that overtopped the central storm ridge and sent lesser clasts down the apparent lee side of the beach to accumulate on a smooth $5^{\circ}$ slope. Such a hypothesis posits that early Holocene storms in the Norwegian Sea were more likely to have arrived from the SW, trending to the NE against the adjacent Norwegian mainland. The downward shift in clast sizes from sample 3 (Figure 9e,f) compared to samples 1 (Figure 9a,b) and 2 (Figure 9c,d) implies that a different wave regime may have been in place on the NE end of the valley compared to the SW end.

\subsection{Inference from Historical Storms}

Observations on the steering winds in Norway's Arctic Vestifjord district north of Leka Island are summarized by Jones et al. (1997), based on information derived from weather stations on small islands in the Norwegian Sea as well as the Norwegian mainland [10]. Cod fishing in this district has a long history as a major industry dating back centuries [23], and the difference between winter and summer weather is well known. During the winter months when the fishing season is in play, the dominant winds arrive from the southwest commonly interpreted as fresh breezes between 4 and 5 on the Beaufort scale. However, there is a $10 \%$ chance that gale-force winds ( 8 on the Beaufort scale) will occur with wind speeds reach $20.7 \mathrm{~m} / \mathrm{s}$. During the summer months, lighter winds generally arrive from the NE and gale-force winds are rare, comprising less than $1 \%$ of station observations [10]. Hurricanes are a seasonal feature of tropical and subtropical settings uncharacteristic for Boreal Seas. 
Technically, they are a tropical to subtropical phenomenon that depends on high ocean-surface water temperatures and excessive air moisture [22]. During the last decade (2011 to 2020), four storms assigned to the category of "orkan" by the Norwegian Meteorological Institute [24-27] struck the Norwegian coast including the vicinity of Leka Island (Table 2). These specific storms share a general history of duration lasting $48 \mathrm{~h}$, or more, with a frequency of arrival every second year. Clearly, these factors play a role in beach dynamics related to clast size.

Table 2. Impact of superstorms in the North Trondelag and Nordland districts of coastal Norway summarized from reports issued by the Norwegian Meteorological Institute.

\begin{tabular}{ccccc}
\hline Storm Name & Date of Landfall & $\begin{array}{c}\text { Direction of } \\
\text { Arrival }\end{array}$ & $\begin{array}{c}\text { Maximum Wind } \\
\text { Speed (m/s) }\end{array}$ & $\begin{array}{c}\text { Maximum Wave } \\
\text { Height (m) }\end{array}$ \\
\hline Dagmar [24] & 25 December 2011 & SW to W & $35-40$ & Unknown \\
Hilde [25] & 16 November 2013 & SW & $40-50$ & $12-24$ \\
Tor [26] & 7 January 2016 & SW & $35-45$ & $9-12$ \\
Cora [27] & 1 January 2018 & SW to NW & $45-55$ & Unknown \\
\hline
\end{tabular}

The direct translation of the Norwegian word "orkan" to English is hurricane, and the NMI's basis for such storms is defined by a minimum wind speed of $32.7 \mathrm{~m} / \mathrm{s}$. Major storms in high latitudes express a cyclonic circulation similar to hurricanes, but originate independently of water vapor arising from excessively high ocean-surface water temperatures. Instead, they rely on the acceleration of weather fronts with extreme contrasts in air temperature on opposite sides of the line [28]. Based on the Saffir-Simpson hurricane wind scale, a wind speed of $32.7 \mathrm{~m} / \mathrm{s}$ falls below the range of a Category 1 hurricane with wind speeds between 33 and $42 \mathrm{~m} / \mathrm{s}$. During the last decade, at least two major storms reached the North Trondelag and Nordland districts of Norway packing maximum wind speeds of $50 \mathrm{~m} / \mathrm{s}$ or higher that according to the Saffir-Simpson scale qualify as Category 3 disturbances. Based on standard energy calculations in mega joules, a high-latitude storm of the kind reaching the mid-section of Norway in recent years expends roughly 50\% of the energy of a large tropical hurricane [28], but such a release is sufficient to do extensive damage to coastal infrastructure and erode coastal shores. It is notable that all four superstorms reaching North Trondelag and Nordland including Leka Island arrived from the southwest (Table 2). The local climate in this area following the retreat of glaciers 10,000 years ago was sure to have been more extreme than today, but the arrival pattern of today's major storms fits with the physical characteristics of Holocene boulder deposits filling Støypet valley. Moreover, it is notable that even the lower range of storm-wave heights reported for Hilde and Tor $[25,26]$ exceed the storm-wave heights estimated to have entered the Holocene channel.5.4. Contrast with Coastal Deposits Elsewhere

Holocene deposits formed by unconsolidated cobbles and boulders are widely distributed all around the world, but studies in coastal geomorphology seldom take into account rock density as related to variability in parent rock types when investigating the range of wave heights necessary for their development. Equation (1) as derived from Nott [17] has been applied to coastal boulder deposits throughout Mexico's Gulf of California, including those formed by limestone, rhyolite, and andesite clasts [6-8]. Extension of this work to include Equation (2) as influenced by Pepe et al. [19] also has been applied to coastal basalt deposits in the Azores [9]. The variation in density among these rock types ranges from $1.86 \mathrm{~g} / \mathrm{cm}^{3}$ for limestone, $2.16 \mathrm{~g} / \mathrm{cm}^{3}$ for the rhyolite, $2.55 \mathrm{~g} / \mathrm{cm}^{3}$ for andesite, and $3.0 \mathrm{~g} / \mathrm{cm}^{3}$ for basalt. Cobbles and boulders of low-grade chromite ore that are the subject of the present study register a higher density measured as $3.32 \mathrm{~g} / \mathrm{cm}^{3}$ and high-grade chromite ore is known to yield an even greater value. Limestone differs from the others as a marine product derived mostly from organic materials, whereas the rest are igneous rocks some of which like rhyolite and andesite typically form under subaerial conditions as volcanic flows. The limestone, rhyolite, and andesite all produce stratified bodies that sooner or later become subject to joints that break perpendicular to the bedding plane. Basalt may issue under subaerial conditions subject to jointing in the same way, but also 
forms under submarine conditions that entail a different style of accumulation as pillow-shaped bodies, typical on Santa Maria Island in the Azores [9]. Dunite and chromite as found exposed on Norway's Leka Island are igneous rocks that originated deep within the Earth's crust but also under conditions that allowed for stratified bodies associated with serial injections of magma that cooled slowly one after the other. The key similarity among all these rock types is the appearance of horizontal partings cut by joints and fractures. In sea cliffs subject to wave erosion, it is the configuration of layering dissected by joints common to all such rocks that determines the effectiveness of storms to detach blocks subsequently incorporated in coastal boulder deposits.

Rock density is an important factor in coastal erosion, because a storm wave of any given height will behave differently depending on the degree of stratification and jointing in the parent sea cliff. The same wave will have the capacity to dislodge a larger, less dense block of limestone compared to a smaller, denser block of basalt or chromite. Another factor to be considered is the difference between tropical hurricanes limited to lower latitudes and Boreal storms characteristic of higher, more poleward latitudes. The largest block detached from a limestone sea cliff by Holocene hurricanes in the Gulf of California is estimated to weigh 28 metric tons [6], whereas limestone blocks between 100 and 200 metric tons are attributed to detachment from sea cliffs in the Philippines during Super Typhoon Haiyan in 2013 [29]. However, the erosional effectiveness of tropical hurricanes compared to Boreal storms is not to be underestimated on account of movements in blocks weighing as much as 620 metric tons during the winter storms of 2013-2014 against limestone sea cliffs in western Ireland [30]. By comparison, the chromite cobbles and boulders entrained as a Holocene beach deposit in Støypet valley are exceedingly small, but with a much greater density than limestone. Studies on the geomorphology of boulder deposits composed of other rock types such as granite and gabbro are to be encouraged.

\section{Conclusions}

Study of the cobble-boulder beach entrained in Støypet valley on Norway's Leka Island offers insights based on mathematical equations for estimation of Holocene wave heights and wave heights from recent superstorms in the same region:

- The unconsolidated cobble-boulder beach preserved as a Holocene deposit in Støypet valley is unique due to components of low-grade chromite ore and the igneous rock dunite that originated deep within the Earth's crust. In particular, chromite is a dense rock seldom exposed at the surface and more rarely in coastal settings subject to wave erosion.

- Present-day Støypet valley originated as a marine channel that separated part of the island's north shore from the rest of the island in early Holocene time when free passage from one end to the other end was possible prior to surface rebound after the retreat of glacial ice. The valley's mid-point is close to $100 \mathrm{~m}$ above present-day sea level with the upper $25 \mathrm{~m}$ occupied by the cobble-boulder beach.

- Data on size variations in clast size from three field samples in Støypet valley suggest that Holocene storms entered the former channel from the SW, which is consistent with the approach by recent storms of hurricane strength on the same coast in North Trondelag and Nordland near the Polar Circle.

- The density of constituent clasts derived from low-grade chromite ore eroded by storm waves from joint-bound sea cliffs is $45 \%$ more dense than limestone boulders and $25 \%$ more dense than andesite boulders previously studied in coastal deposits elsewhere. Although chromite boulders from Leka Island are small in comparison, the energy expended by storm waves to free blocks of chromite from joint-bound sea cliffs would have been greater normalized for unit volume than for limestone or other igneous rocks like andesite.

- Different equations used to estimate the height of storm waves eroding sea cliffs with joint-bound rocks differ in results as found in the formulations applied from Nott [17] and updated by 
Pepe et al. [19]. In this study, the latter yielded estimates from $12 \%$ to $24 \%$ higher depending on analysis of mean clast size or maximum clast size. Holocene wave heights estimated by both equations are within the range of observed wave heights during major storms in the same region.

The Norwegian National Geological Monument within the Trollfjell (Troll Mountain) Geopark already provides an outstanding resource for visitors of all ages and educational backgrounds to learn about earth processes and achieve a better appreciation for our common geoheritage. Its significance can be expected to grow with visitors offering fresh input from different perspectives.

Funding: The research project received no external funding.

Acknowledgments: B. Gudveig Baarli organized the logistics for a visit to Leka Island and assisted in the collection of field data in Støypet valley in July 2019. Sérgio P. Ávila (University of the Azores) provided the calculations for wave heights based on the mathematical model influenced by Pepe et al. (2018). The author is grateful for recommendations offered by three anonymous reviewers that helped him to improve the final product, as well as crucial comments provided by the scientific advisor.

Conflicts of Interest: The author declares no conflict of interest.

\section{Appendix A}

Table A1. Quantification of clast size, volume, and estimated weight from a sample on the SW flank of Støypet (locality 1). The density of low-grade chromite at $3.32 \mathrm{~g} / \mathrm{cm}^{3}$ is applied uniformly in order to calculate wave height for each boulder. Abbreviation: EWH = estimated wave height.

\begin{tabular}{|c|c|c|c|c|c|c|c|c|}
\hline Sample & $\begin{array}{l}\text { Long } \\
\text { Axis } \\
(\mathrm{cm})\end{array}$ & $\begin{array}{l}\text { Intermediate } \\
\text { Axis } \\
\text { (cm) }\end{array}$ & $\begin{array}{l}\text { Short } \\
\text { Axis } \\
\text { (cm) }\end{array}$ & $\begin{array}{c}\text { Volume } \\
\left(\mathrm{cm}^{3}\right)\end{array}$ & $\begin{array}{l}\text { Adjust } \\
\text { to } 80 \%\end{array}$ & $\begin{array}{l}\text { Weight } \\
\text { (kg) }\end{array}$ & $\begin{array}{c}\text { Ewh } \\
\text { Nott [17] } \\
\text { (m) }\end{array}$ & $\begin{array}{c}\text { Ewh Pepe } \\
\text { et al. [19] } \\
\text { (m) }\end{array}$ \\
\hline 1 & 29 & 19 & 16 & 8816 & 7053 & 23 & 3.7 & 4.6 \\
\hline 2 & 22 & 18 & 18 & 7128 & 5702 & 19 & 2.8 & 5.2 \\
\hline 3 & 24 & 22 & 12 & 6336 & 5069 & 17 & 3.1 & 3.4 \\
\hline 4 & 23 & 14 & 12 & 3864 & 3091 & 10 & 3.0 & 3.4 \\
\hline 5 & 25 & 18 & 6 & 2700 & 2160 & 7 & 3.2 & 1.7 \\
\hline 6 & 18 & 14 & 11 & 2772 & 2218 & 7 & 2.3 & 3.1 \\
\hline 7 & 32 & 17 & 12 & 6528 & 5222 & 17 & 4.1 & 3.4 \\
\hline 8 & 23 & 20 & 20 & 9200 & 7360 & 24 & 3.0 & 5.7 \\
\hline 9 & 32 & 17 & 15 & 8160 & 6528 & 22 & 4.1 & 4.3 \\
\hline 10 & 34 & 20 & 20 & 13,600 & 10,880 & 36 & 4.4 & 5.7 \\
\hline 11 & 30 & 20 & 20 & 12,000 & 9600 & 32 & 3.9 & 5.7 \\
\hline 12 & 26 & 19 & 15 & 7410 & 5928 & 20 & 3.4 & 4.3 \\
\hline 13 & 50 & 30 & 28 & 42,000 & 33,600 & 112 & 6.5 & 8.0 \\
\hline 14 & 34 & 23 & 20 & 15,640 & 12,512 & 42 & 4.4 & 5.7 \\
\hline 15 & 27 & 24 & 17 & 11,016 & 8813 & 29 & 3.5 & 4.9 \\
\hline 16 & 24 & 24 & 20 & 11,520 & 9216 & 31 & 3.1 & 5.7 \\
\hline 17 & 22 & 17 & 10 & 3740 & 2992 & 10 & 2.8 & 2.9 \\
\hline 18 & 28 & 20 & 18 & 10,080 & 8064 & 27 & 3.6 & 5.2 \\
\hline 19 & 26 & 18 & 16 & 7488 & 5990 & 20 & 3.4 & 4.6 \\
\hline 20 & 23 & 17 & 15 & 5865 & 4692 & 16 & 3.0 & 4.3 \\
\hline 21 & 44 & 30 & 27 & 35,640 & 28,512 & 95 & 5.7 & 7.7 \\
\hline 22 & 26 & 20 & 14 & 7280 & 5824 & 19 & 3.4 & 4.0 \\
\hline 23 & 26 & 17 & 14 & 6188 & 4950 & 16 & 3.4 & 4.0 \\
\hline 24 & 26 & 14 & 14 & 5096 & 4077 & 14 & 3.4 & 4.0 \\
\hline 25 & 23 & 14 & 13 & 4186 & 3349 & 11 & 3.0 & 3.7 \\
\hline Average & 27.9 & 19.4 & 16.1 & 10,170 & 8136 & 27 & 3.6 & 4.6 \\
\hline
\end{tabular}


Table A2. Quantification of clast size, volume, and estimated weight from a sample at the top of the pass at Støypet (Locality 2). The density of low-grade chromite at $3.32 \mathrm{~g} / \mathrm{cm}^{3}$ is applied uniformly in order to calculate wave height for each boulder. Abbreviation: $\mathrm{EWH}=$ estimated wave height.

\begin{tabular}{|c|c|c|c|c|c|c|c|c|}
\hline Sample & $\begin{array}{l}\text { Long } \\
\text { Axis } \\
\text { (cm) }\end{array}$ & $\begin{array}{l}\text { Intermediate } \\
\text { Axis } \\
\text { (cm) }\end{array}$ & $\begin{array}{l}\text { Short } \\
\text { Axis } \\
\text { (cm) }\end{array}$ & $\begin{array}{c}\text { Volume } \\
\left(\mathrm{cm}^{3}\right)\end{array}$ & $\begin{array}{l}\text { Adjust } \\
\text { to } 80 \%\end{array}$ & $\begin{array}{l}\text { Weight } \\
\text { (kg) }\end{array}$ & $\begin{array}{c}\text { EWH } \\
\text { Nott [17] } \\
\text { (m) }\end{array}$ & $\begin{array}{c}\text { EWH Pepe } \\
\text { et al. [19] } \\
\text { (m) }\end{array}$ \\
\hline 1 & 38 & 21 & 16 & 12,768 & 10,214 & 34 & 4.9 & 4.6 \\
\hline 2 & 33 & 22 & 19 & 13,794 & 11,035 & 37 & 4.3 & 5.4 \\
\hline 3 & 42 & 26 & 19 & 20,748 & 16,995 & 56 & 5.4 & 5.4 \\
\hline 4 & 27 & 20 & 12 & 6480 & 5184 & 17 & 3.3 & 3.4 \\
\hline 5 & 32 & 16 & 15 & 7680 & 6144 & 20 & 4.1 & 4.3 \\
\hline 6 & 27 & 15 & 10 & 4050 & 3240 & 11 & 3.3 & 2.9 \\
\hline 7 & 22 & 20 & 18 & 7920 & 6336 & 21 & 2.8 & 5.2 \\
\hline 8 & 33 & 23 & 16 & 12,144 & 9715 & 32 & 4.3 & 4.6 \\
\hline 9 & 26 & 19 & 18 & 8892 & 7113 & 24 & 3.4 & 5.2 \\
\hline 10 & 36 & 22 & 16 & 12,672 & 10,137 & 34 & 4.7 & 4.6 \\
\hline 11 & 24 & 19 & 13 & 5928 & 4742 & 16 & 3.1 & 3.7 \\
\hline 12 & 29 & 20 & 18 & 10,440 & 8352 & 28 & 3.7 & 5.2 \\
\hline 13 & 26 & 20 & 19 & 9880 & 7904 & 26 & 3.4 & 5.4 \\
\hline 14 & 26 & 17 & 16 & 7072 & 5658 & 19 & 3.4 & 4.6 \\
\hline 15 & 46 & 26 & 20 & 23,920 & 19,136 & 64 & 5.9 & 5.7 \\
\hline 16 & 29 & 20 & 11 & 6380 & 5104 & 17 & 3.7 & 3.1 \\
\hline 17 & 37 & 28 & 25 & 23,125 & 18,500 & 61 & 4.8 & 7.2 \\
\hline 18 & 30 & 29 & 13 & 11,310 & 9048 & 30 & 3.9 & 3.7 \\
\hline 19 & 35 & 29 & 20 & 20,300 & 16,240 & 54 & 4.5 & 5.7 \\
\hline 20 & 33 & 23 & 20 & 15,180 & 12,144 & 40 & 4.3 & 5.7 \\
\hline 21 & 30 & 19 & 19 & 10,830 & 8664 & 29 & 3.9 & 5.4 \\
\hline 22 & 23 & 18 & 14 & 5796 & 4637 & 15 & 3.0 & 4.0 \\
\hline 23 & 30 & 22 & 17 & 11,220 & 8976 & 30 & 3.9 & 4.9 \\
\hline 24 & 40 & 30 & 22 & 26,400 & 21,120 & 70 & 5.2 & 6.3 \\
\hline 25 & 34 & 18 & 17 & 10,404 & 8323 & 28 & 4.4 & 4.9 \\
\hline Average & 31.5 & 21.7 & 17 & 12,213 & 9786 & 33 & 4.1 & 4.8 \\
\hline
\end{tabular}

Table A3. Quantification of clast size, volume, and estimated weight from a sample on the NE flank of Støypet (Locality 3). The density of low-grade chromite at $3.32 \mathrm{~g} / \mathrm{cm}^{3}$ is applied uniformly in order to calculate wave height for each boulder. Abbreviation: $\mathrm{EWH}=$ estimated wave height.

\begin{tabular}{|c|c|c|c|c|c|c|c|c|}
\hline Sample & $\begin{array}{l}\text { Long } \\
\text { Axis } \\
\text { (cm) }\end{array}$ & $\begin{array}{l}\text { Intermediate } \\
\text { Axis } \\
\text { (cm) }\end{array}$ & $\begin{array}{l}\text { Short } \\
\text { Axis } \\
(\mathrm{cm})\end{array}$ & $\begin{array}{l}\text { Volume } \\
\left(\mathrm{cm}^{3}\right)\end{array}$ & $\begin{array}{l}\text { Adjust } \\
\text { to } 80 \%\end{array}$ & $\begin{array}{c}\text { Weight } \\
\text { (kg) }\end{array}$ & $\begin{array}{c}\text { EWH } \\
\text { Nott [17] } \\
\text { (m) }\end{array}$ & $\begin{array}{c}\text { EWH Pepe } \\
\text { et al. [19] } \\
\text { (m) }\end{array}$ \\
\hline 1 & 29 & 20 & 16 & 9280 & 7424 & 25 & 3.7 & 4.6 \\
\hline 2 & 30 & 19 & 18 & 10,260 & 8208 & 27 & 3.9 & 5.2 \\
\hline 3 & 34 & 20 & 16 & 10,880 & 8704 & 29 & 4.4 & 4.6 \\
\hline 4 & 26 & 15 & 15 & 5850 & 4680 & 16 & 3.4 & 4.3 \\
\hline 5 & 29 & 20 & 14 & 8120 & 6496 & 22 & 3.7 & 4.0 \\
\hline 6 & 26 & 21 & 12 & 6552 & 5242 & 17 & 3.4 & 3.4 \\
\hline 7 & 24 & 20 & 14 & 6720 & 5376 & 18 & 3.1 & 4.0 \\
\hline 8 & 21 & 16 & 8 & 2688 & 2150 & 7 & 2.7 & 2.3 \\
\hline 9 & 20 & 19 & 13 & 4940 & 3952 & 13 & 2.6 & 3.7 \\
\hline 10 & 17 & 17 & 16 & 4624 & 3699 & 12 & 2.2 & 4.6 \\
\hline 11 & 18 & 15 & 13 & 3510 & 2808 & 9 & 2.3 & 3.7 \\
\hline 12 & 26 & 17 & 10 & 4420 & 3536 & 12 & 3.4 & 2.9 \\
\hline 13 & 27 & 20 & 16 & 8640 & 6912 & 23 & 3.5 & 4.6 \\
\hline 14 & 27 & 20 & 10 & 5400 & 4320 & 14 & 3.5 & 2.9 \\
\hline 15 & 32 & 24 & 15 & 11,520 & 9216 & 31 & 4.1 & 4.3 \\
\hline
\end{tabular}


Table A3. Cont.

\begin{tabular}{|c|c|c|c|c|c|c|c|c|}
\hline Sample & $\begin{array}{l}\text { Long } \\
\text { Axis } \\
\text { (cm) }\end{array}$ & $\begin{array}{l}\text { Intermediate } \\
\text { Axis } \\
\text { (cm) }\end{array}$ & $\begin{array}{l}\text { Short } \\
\text { Axis } \\
\text { (cm) }\end{array}$ & $\begin{array}{c}\text { Volume } \\
\left(\mathrm{cm}^{3}\right)\end{array}$ & $\begin{array}{l}\text { Adjust } \\
\text { to } 80 \%\end{array}$ & $\begin{array}{l}\text { Weight } \\
\text { (kg) }\end{array}$ & $\begin{array}{c}\text { EWH } \\
\text { Nott [17] } \\
\text { (m) }\end{array}$ & $\begin{array}{c}\text { EWH Pepe } \\
\text { et al. [19] } \\
\text { (m) }\end{array}$ \\
\hline 16 & 24 & 12 & 11 & 3168 & 2534 & 8 & 3.1 & 3.1 \\
\hline 17 & 30 & 20 & 13 & 7800 & 6240 & 21 & 3.9 & 3.7 \\
\hline 18 & 28 & 27 & 12 & 13,608 & 10,886 & 36 & 3.6 & 3.4 \\
\hline 19 & 20 & 15 & 6 & 1800 & 1440 & 5 & 2.6 & 1.7 \\
\hline 20 & 18 & 13 & 8 & 1872 & 1498 & 5 & 2.3 & 2.3 \\
\hline 21 & 26 & 20 & 8 & 4160 & 3328 & 11 & 3.4 & 2.3 \\
\hline 22 & 26 & 22 & 13 & 7436 & 5949 & 20 & 3.4 & 3.7 \\
\hline 23 & 25 & 20 & 8 & 4000 & 3200 & 11 & 3.2 & 2.3 \\
\hline 24 & 25 & 20 & 10 & 5000 & 4000 & 13 & 3.2 & 2.9 \\
\hline 25 & 20 & 15 & 8 & 2400 & 1920 & 6 & 2.6 & 2.3 \\
\hline Average & 25 & 18.7 & 12 & 6186 & 4949 & 16 & 3.2 & 3.5 \\
\hline
\end{tabular}

\section{References}

1. Farsani, N.T.; Coelho, C.; Costa, C. Geotourism and geoparks as novel strategies for socio-economic development in rural areas. Int. J. Tour. Res. 2011, 13, 68-81. [CrossRef]

2. Olafsdóttir, R.; Dowling, R. Geotourism and geoparks-A tool for geoconservation and rural development in vulnerable environments: A case study from Iceland. Geoheritage 2014, 6, 71-87. [CrossRef]

3. Dahl, R.M.E.; Carstens, H.; Haukdal, G. The election of a National Norwegian Geological Monument: At tool for raising awareness of geological Heritage. GeoJ. Tour. Geosites 2011, 4, 178-184.

4. Prestvik, T. Alpine-type mafic and ultramafic rocks of Leka, Nord-Trøndelog. Nor. Geol. Unders. 1972, 273, 23-24.

5. Pedersen, R.-B.; Johannesen, G.M.; Boyd, R. Stratiform platinum-group element mineralization in the ultramafic cumulates of the Leka Ophiolite Complex, Central Norway. Econ. Geol. 1993, 88, 782-803. [CrossRef]

6. Johnson, M.E.; Ledesma-Vázquez, J.; Guardado-France, R. Coastal geomorphology of a Holocene hurricane deposit on a Pleistocene marine terrace from Isla Carmen (Baja California Sur, Mexico). J. Mar. Sci. Eng. 2018, 6, 108. [CrossRef]

7. Johnson, M.E.; Guardado-France, R.; Johnson, E.M.; Ledesma-Vázquez, J. Geomorphology of a Holocene Hurricane deposit eroded from rhyolite sea cliffs on Ensenada Almeja (Baja California Sur, Mexico). J. Mar. Sci. Eng. 2019, 7, 193. [CrossRef]

8. Johnson, M.E.; Guardado-France, R.; Ledesma-Vázquez, J. Holocene hurricane deposits eroded as coastal barriers from andesite sea cliffs at Puerto Escondido (Baja California Sur, Mexico). J. Mar. Sci. Eng. 2020, 8, 75. [CrossRef]

9. Ávila, S.P.; Johnson, M.E.; Rebelo, A.C.; Baptista, L.; Melo, C.S. Comparison of modern and Pleistocene (MIS 5e) coastal Boulder deposits from Santa Maria Island (Azores Archipelago, NE Atlantic Ocean). J. Mar. Sci. Eng. 2020, 8, 386. [CrossRef]

10. Jones, B.; Boudjelas, S.; Mitchelson-Jacob, E.G. Topographic steering of winds in Vestfjorden, Norway. Weather 1997, 52, 304-311. [CrossRef]

11. Høgaas, F.; Sveian, H. The Younger Dryas Main Line on Leka Norway, as determined from a high resolution digital elevation model derived from airborne LiDAR data. Geomorphology 2015, 231, 63-71. [CrossRef]

12. Burzynski, M. Gros Morne National Park; Breakwater Books, Ltd.: St. John's, NL, Canada, 1999.

13. Wentworth, C.K. A scale of grade and class terms for clastic sediments. J. Geol. 1922, 27, 377-392. [CrossRef]

14. Ruban, D.A. Costal boulder deposits of the Neogene world: A synopsis. J. Mar. Sci. Eng. 2019, 7, 446. [CrossRef]

15. Sneed, E.D.; Folk, R.L. Pebbles in the lower Colorado River of Texas: A study in particle morphogenesis. J. Geol. 1958, 66, 114-150. [CrossRef]

16. Leka Commune Authority. Leka Turkart (målestokk 1:35 000). Single-Sheet Folded Map; Leka Commune Authority: Stockholm, Sweden, 2017.

17. Nott, J. Waves, coastal bolder deposits and the importance of pre-transport setting. Earth Planet. Sci. Lett. 2003, 210, 269-276. [CrossRef] 
18. Nandasena, N.A.K.; Paris, R.; Tanaka, N. Reassessment of hydrodynamic equations: Minimum flow velocity to initiate boulder transport by high energy events (storms, tsunamis). Mar. Geol. 2011, 281, 70-84. [CrossRef]

19. Pepe, F.; Corradino, M.; Parrino, N.; Besio, G.; Presti, V.L.; Renda, P.; Calcagnile, L.; Quarta, G.; Sulli, A.; Antonioli, F. Boulder coastal deposits at Favignana Island rocky coast (Sicily, Italy): Litho-structural and hydrodynamic control. Geomorphology 2018, 303, 191-209. [CrossRef]

20. Nash, G.; Smiseth, M.T. Art and intimacy within the prehistoric landscapes of Norway. In Ritual Landscapes and Borders within Rock Art Research; Stebergløkken, H., Berge, R., Lindgaard, E., Stuedal, H.V., Eds.; Archaeopress Publ. Ltd.: Oxford, UK, 2015; pp. 31-46. ISBN 978-1-78491-159-1.

21. Møller, J.J. Shoreline relation and prehistoric settlement in northern Norway. Nor. Geogr. Tidsskr. 1987, 41, 45-60. [CrossRef]

22. May, S.M.; Engel, M.; Brill, D.; Squire, P.; Scheffers, A.; Kelletat, D. Coastal hazards from tropical cyclones and extratropical winter storms based on Holocene storm chronologies. In Coastal Hazards; Finkl, C.W., Ed.; Springer: Berlin/Heidelberg, Germany, 2013; Volume 6, pp. 557-585.

23. Dass, P. The Trumpet of Nordland; Helgaland Museum: Mosjøen, Norway, 2015.

24. Kvamme, D.; Abildsnes, H. Ekstremev Ær Rapport DAGMAR, 25 December 2011. Norsk Meteorologisk Institute. 2012, Dagmar E-Rapport. p. 52. Available online: https://www.met.no/ publikasjoner/met-info/ekstremvaer/_attachment/download/69803fbb-7c26-41ce-83e9-0479891c043d: c28f40bfb1fd2c4a07672bd8132b40bcc44717c3/dagmar-e-rapport.pdf (accessed on 21 August 2020).

25. Anonymous. Ekstremev Ær Rapport HILDE, 16-17 November 2013. Norsk Meteorologisk Institute. 2013. Hilde E-Rapport. p. 19. Available online: https://www.met.no/ publikasjoner/met-info/ekstremvaer/_attachment/download/eacf68c3-9237-417b-b8bc-6feb2af01dea: ccc0476b8d4ecb716bd14a80b8da590c71971b55/ekstrem_rapport_hilde.pdf (accessed on 21 August 2020).

26. Anonymous. Ekstremev Ær Rapport TOR, 29-30 January 2016. Norsk Meteorologisk Institute. 2016. Tor E-Rapport. p. 19. Available online: https://www.met.no/ publikasjoner/met-info/ekstremvaer/_attachment/download/f9f30fbc-e10a-43bf-8ac8-54f35139ced7: 04f39c24d58c79b43cdcf924b62e4192e5d3926c/MET-info-14-2016.pdf (accessed on 21 August 2020).

27. Olsen, A.-M.; Berge, H. Ekstremev Ær Rapport CORA, January 2018. Norsk Meteorologisk Institute. 2018. Cora E-Rapport. p. $16 . \quad$ Available online: https://www.met.no/ publikasjoner/met-info/ekstremvaer/_attachment/download/099ee978-df9a-4a35-88f1-9b8ece0ccea1: d9f7f511ab78b9e517275c3818b72880d4626310/Met-info-14-2018.pdf (accessed on 21 August 2020).

28. Pielou, E.C. The Energy of Nature; University of Chicago Press: Chicago, IL, USA, 2001.

29. Kennedy, A.B.; Mori, N.; Yasuda, T.; Shimozono, T.; Tomiczek, T.; Donahue, A.; Shimura, T.; Imai, Y. Extreme block and boulder transport along a cliffed coastline (Calicoan Island, Philippines) during Super Typhoon Haiyan. Mar. Geol. 2017, 383, 65-77. [CrossRef]

30. Cox, R.; Jahn, K.L.; Watkins, O.G.; Cox, P. Extraordinary boulder transport by storm waves (west of Ireland, winter 2013-2014), and criteria for analyzing coastal boulder deposits. Earth Sci. Rev. 2018, 177, 623-636. [CrossRef]

(C) 2020 by the author. Licensee MDPI, Basel, Switzerland. This article is an open access article distributed under the terms and conditions of the Creative Commons Attribution (CC BY) license (http://creativecommons.org/licenses/by/4.0/). 